\title{
EFEKTIVITAS MODEL PEMBELAJARAN PORTOFOLIO DAN MODEL PEMBELAJARAN KOOPERATIF THINK PAIR AND SHARE (TPS) TERHADAP PRESTASI BELAJAR MATEMATIKA DITINJAU DARI KREATIVITAS SISWA VII SMP NEGERI 2 KEBONSARI TAHUN AJARAN 2011/2012
}

\author{
Vera Dewi Susanti \\ Dosen Program Studi Pendidikan Matematika FPMIPA IKIP PGRI Madiun
}

Email : veradewisusanti@yahoo.co.id.

\begin{abstract}
Abstrak. Tujuan penelitian ini adalah untuk mengetahui: (1) apakah ada perbedaan pengaruh model pembelajaran portofolio maupun model pembelajaran kooperatif think pair and share (TPS) dalam meningkatkan prestasi belajar matematika siswa, (2) apakah ada perbedaan pengaruh antara kreativitas tinggi dan rendah terhadap prestasi belajar matematika siswa, (3) apakah ada interaksi antara model pembelajaran portofolio dan model pembelajaran kooperatif think pair and share (TPS) baik pada siswa yang mempunyai kreativitas tinggi maupun rendah terhadap prestasi belajar matematika siswa.

Sebagai populasi dalam penelitian ini adalah siswa SMP Negeri 2 Kebonsari tahun ajaran 2011/2012. Penentuan sampel dengan teknik random sampling yaitu 56 siswa dari siswa-siswa kelas eksperimen dan kelas kontrol. Kelas eksperimen menggunakan model pembelajaran portofolio dan kelas kontrol menggunakan model pembelajaran kooperatif think pair and share (TPS). Teknik pengumpulan data untuk kreativitas menggunakan angket dan data prestasi belajar menggunakan tes. Uji hipotesis penelitian menggunakan anava dua jalan sel tak sama. Uji lanjut pasca anava menggunakan uji Scheffe.

Dari hasil analisis data didapatkan: 1) ada perbedaan pengaruh antara model pembelajaran portofolio dan model pembelajaran kooperatif think pair and share (TPS) dalam meningkatkan prestasi belajar matematika siswa (nilai signifikansi $<0,05$ ); 2) ada perbedaan pengaruh antara kreativitas tinggi dan kreativitas rendah terhadap prestasi belajar matematika siswa (nilai signifikansi $<0,05$ ); 3 ) tidak terdapat interaksi antara model pembelajaran portofolio dan model pembelajaran kooperatif think pair and share (TPS) dengan kreativitas tinggi maupun rendah terhadap prestasi belajar matematika siswa (nilai signifikansi $>0,05)$.
\end{abstract}

Kata Kunci : Efektifitas, Model Pembelajaran Portofolio, Model Pembelajaran Kooperatif Think Pair and Share (TPS), Prestasi belajar matematika, Kreativitas

\section{PENDAHULUAN}

Pendidikan adalah salah satu pilar utama yang memungkinkan suatu negara mengalami kemajuan dalam bidang pengetahuan dan teknologi. Tujuan utama pengelolaan pendidikan yaitu terjadinya proses belajar dan pengalaman belajar yang optimal. Dalam keseluruhan proses pendidikan di sekolah, kegiatan belajar mengajar merupakan kegiatan yang paling pokok, ini berarti berhasil tidaknya pencapaian tujuan pendidikan banyak bergantung kepada bagaimana proses belajar mengajar dan pembelajaran yang dialami siswa.

Dunia pendidikan saat ini hanya memusatkan mutu pendidikan pada peningkatan Kegiatan Belajar Mengajar (KBM) yang di dalamnya terdapat guru dan siswa yang memiliki perbedaan kemampuan, ketrampilan, filsafat hidup dan lain sebagainya. Adanya perbedaan tersebut menjadikan pembelajaran sebagai proses pendidikan yang memerlukan pendekatan, metode, dan teknik yang bermacam-macam sehingga siswa dapat menguasai materi dengan baik dan mendalam. Penguasaan siswa pada pencapaian aspek suatu materi dapat dilihat dari kecakapan yang dimiliki oleh siswa itu sendiri salah satunya melalui kemampuan siswa dalam memecahkan masalah melalui kreativitas yang dimilikinya.

Matematika merupakan pelajaran yang relatif sulit dan rumit dipahami oleh siswa, sehingga diperlukan pemahaman yang serius jika dikaitkan dengan kemampuan siswa dalam memecahkan masalah. Sebagian besar siswa belum mampu menghubungkan materi yang dipelajari dengan pengetahuan yang digunakan atau dimanfaatkan. Hal ini disebabkan karena penggunaan sistem pembelajaran yang kurang tepat yaitu siswa hanya diberi pengetahuan secara lisan (ceramah). Sedangkan di sisi lain siswa membutuhkan konsep-konsep yang berhubungan dengan lingkungan sekitarnya. Karena belajar matematika bukan hanya 
transfer pengetahuan tetapi sesuatu yang harus dipahami oleh siswa yang akan diperlukan dalam kehidupan sehari-hari. Belajar matematika akan lebih bermakna jika siswa mengalami sendiri apa yang dipelajari daripada hanya mengetahui secara lisan saja.

Selain kemampuan dalam memecahkan masalah, kreativitas dari masing-masing siswa sangat diperlukan untuk memecahkan permasalahan-permasalahan yang ada dalam matematika. Kreativitas antara siswa satu dengan yang lain pasti berbeda, ini yang menimbulkan berbagai perbedaan pendapat yang akhirnya tercipta banyak inovasi baru dari siswa.

Kreativitas merupakan suatu bidang kajian yang kompleks, yang menimbulkan berbagai perbedaan pandangan. Definisi kreativitas tergantung pada segi penekanannya. Jenis penekanan tersebut adalah penekanan pada individu sendiri, penekanan pada proses berpikir, penekanan dari dorongan eksternal maupun internal, dan penekanan pada produk yang dihasilkan oleh individu. Proses pemecahan masalah dengan kreativitas memberikan kesempatan kepada siswa untuk berperan aktif dalam mempelajari, mencari, dan menemukan data atau informasi yang diolah menjadi konsep, prinsip, teori atau kesimpulan. Sedangkan kreativitas siswa di SMP Negeri 2 Kebonsari masih sangat rendah, hal ini terlihat tidak adanya keinginan siswa untuk menemukan hal-hal baru dalam pembelajaran sehari-hari. Oleh karena itu diperlukan model pembelajaran yang tepat untuk mentransfer bakat dan kreativitas dari masing-masing siswa.

Salah satu model pembelajaran yang dianggap peneliti dapat meningkatkan prestasi belajar siswa adalah model pembelajaran portofolio. Disini siswa dituntut untuk aktif dalam Kegiatan Belajar Mengajar (KBM). Guru hanya sebagai fasilitator sehingga kreativitas siswa dapat tersalurkan dengan baik.

Model pembelajaran portofolio adalah suatu inovasi pembelajaran yang dirancang untuk membantu siswa memahami teori secara mendalam melalui proses belajar. Penggunaan portofolio dalam penilaian proses dan hasil belajar matematika dapat terfokus pada proses belajar mengajar dan memberikan informasi tentang kelebihan dan kekurangan siswa. Trianto (2009: 275) menyatakan portofolio merupakan terjemahan dari bahasa inggris 'portfolio', yang berarti kumpulan berkas ataupun diarsip dalam file khusus. Dalam portofolio berisi koleksi pekerjaan siswa yang menunjukkan segala usaha siswa, kemajuan dan pencapaian belajar dalam satu bidang tertentu. Model pembelajaran yang lain adalah model pembelajaran kooperatif think pair and share (TPS) yaitu model pembelajaran yang memberikan kesempatan kepada setiap siswa untuk menunjukkan partisipasi kepada orang lain. Model Think Pair Share pertama kali dikembangkan oleh Frank Lyman dan rekan-rekannya di Universitas Maryland yang dikutip Arends (dalam Trianto, 2009: 81), menyatakan bahwa Think Pair Share merupakan suatu cara yang efektif untuk membuat variansi suasana pola diskusi kelas.

\section{Metode}

Penelitian ini termasuk penelitian kuantitatif. Sesuai dengan tujuan penelitian maka dalam penelitian ini menggunakan metode eksperimen, yaitu bagian dari metode kuantitatif yang digunakan untuk mencari pengaruh perlakuan tertentu terhadap yang lain dalam kondisi yang terkendalikan .

Dalam penelitian ini terdapat dua variabel yaitu variabel bebas dan variabel terikat.

a. Variabel Independen (Variabel Bebas) adalah variabel yang mempengaruhi atau yang menjadi sebab perubahannya atau timbulnya variabel dependen (terikat). Dalam penelitian ini variabel bebasnya adalah model pembelajaran portofolio, TPS, dan kreativitas.

b. Variabel Dependen (Variabel Terikat) adalah variabel yang dipengaruhi atau yang menjadi akibat karena adanya variabel bebas. Dalam penelitian ini variabel terikatnya adalah prestasi belajar matematika.

Eksperimen dilaksanakan pada siswasiswi SMP Negeri 2 Kebonsari dengan mengambil 2 kelas. Satu kelas dilaksanakan model pembelajaran portofolio sedangkan satu kelas yang lain dilaksanakan model TPS. Dalam penelitian ini, peneliti menggunakan angket kreativitas, tes prestasi dan dokumentasi. Teknik analisis data yang digunakan adalah validitas, reliabilitas, tingkat kesukaran, dan daya pembeda. Untuk angket kreativitas, peneliti hanya mencari validitas dan reliabilitasnya saja. 
Berdasarkan data awal yang diperoleh peneliti di lapangan, data tersebut diolah dengan uji keseimbangan yang meliputi: uji normalitas, uji homogenitas, dan uji t. Setelah data awal yang diperoleh seimbang, peneliti menentukan kelas VIIA sebagai kelas eksperimen dan VIIB sebagai kelas kontrol.

Uji prasyarat analisis (1) dengan uji normalitas data berdistribusi normal; (2) uji homogenitas data, apakah kedua kelas dalam keadaan homogen; (3) uji hipotesis, dengan menggunakan anava dua jalan sel tak sama.

\section{Hasil}

Berdasarkan uji validitas, reliabilitas, tingkat kesukaran, dan daya pembeda instrumen diperoleh hasil 22 butir soal angket kreativitas dan 20 butir soal tes prestasi yang digunakan peneliti untuk mendapatkan data dalam penelitian ini. Data kemampuan awal yaitu data hasil belajar pokok bahasan himpunan digunakan untuk uji keseimbangan dengan prasyarat populasi normal dan homogen.

Hasil uji normalitas berdasarkan kemampuan awal pada kelas eksperimen diperoleh

$D K=\left\{L \mid L>L_{\mathrm{Q}, 08: 27}\right\}=\{L \mid L>0,168\}$

Dan Lobs $=0,109$ sehingga $\mathrm{H}_{0}$ diterima. Hasil uji normalitas berdasarkan kemampuan awal pada kelas control diperoleh $D K=\left\{L \mid L>L_{\mathrm{Q}, 0 \mathrm{x}, \mathrm{x} x}\right\}=\{L \mid L>0,163\}$

dan Lobs $=0,133$ sehingga $\mathrm{H}_{0}$ diterima. Hal ini berarti sampel siswa kelas eksperimen dan sampel siswa kelas control berasal dari populasi yang berdistribusi normal. Hasil uji homogenitas variansi kelas eksperimen dan kelas control berdasarkan kemampuan awal diperoleh

$-\left\{Z^{2} \mid Z^{2}>Z^{2}\right\}-\left[Z^{2} \square Z^{2}>3,862\right]$

dan

$\chi^{2}{ }^{2}{ }^{-0,03 s}$ sehingga $\mathrm{H}_{0}$ diterima. Hal ini berarti variansi kelas eksperimen dan variansi kelas control adalah sama atau homogen. Berikut hasil uji keseimbangan dengan uji $t$ dan prasyarat populasi normal dan homogen.

\begin{tabular}{|l|c|c|c|c|c|}
\hline $\begin{array}{c}\text { Uji } \\
\text { Keseimbangan }\end{array}$ & Dk & $\mathrm{t}_{\mathrm{zbs}}$ & $\mathrm{t}_{\mathrm{0}, \mathrm{grs} ; \mathrm{sk}}$ & Kptsn & Ksmpln \\
\hline $\begin{array}{l}\text { K.eksperimen } \\
\text { Vs K.kontrol }\end{array}$ & 54 & 0,56 & 1,960 & $\begin{array}{c}H_{0} \\
\text { diterima }\end{array}$ & Seimbang \\
\hline
\end{tabular}

Setelah uji normalitas, homogenitas, independensi dilakukan uji variansi. Hasil analisis variansi hasil belajar pokok bahasan garis dan sudut adalah sebagai berikut.

\begin{tabular}{ccccccc}
\hline Sumber & JK & $\mathrm{dk}$ & $\mathrm{RK}$ & $\mathrm{F}_{o b s}$ & $\mathrm{~F}_{a}$ & Kptsn \\
\hline $\begin{array}{c}\text { M.Pembel } \\
\text { ajaran (A) }\end{array}$ & $\begin{array}{c}1330, \\
9\end{array}$ & 1 & $\begin{array}{c}1330, \\
9\end{array}$ & 32,4 & 4,03 & Ditolak \\
$\begin{array}{c}\text { Kreativitas } \\
\text { (B) }\end{array}$ & $\begin{array}{c}4566, \\
8\end{array}$ & 1 & $\begin{array}{c}4566, \\
8\end{array}$ & 111,3 & 4,03 & Ditolak \\
$\begin{array}{c}\text { Interaksi } \\
\text { (AB) }\end{array}$ & 0,42 & 1 & 0,42 & 0,01 & 4,03 & $\begin{array}{c}\text { Diterim } \\
\text { a }\end{array}$ \\
Galat & $\begin{array}{c}2134, \\
2\end{array}$ & 52 & 41,04 & - & - & - \\
Total & 8032, & 55 & - & - & - & - \\
\hline
\end{tabular}

Berdasarkan analisis variansi dua jalan sel tak sama

$\mathrm{H}_{0 \mathrm{~A}} \cdot \mathrm{H}_{0 \mathrm{~B}}$ ditolak dan $\mathrm{H}_{0 \mathrm{AB}}$ diterima, maka dilakukan uji lanjut pasca anava.

\begin{tabular}{cccc}
$\begin{array}{c}\text { Model } \\
\text { Pembelajaran }\end{array}$ & \multicolumn{2}{c}{ Kreativitas } & $\begin{array}{c}\text { Rataan } \\
\text { Targinal }\end{array}$ \\
\hline Portofolio & 87,143 & 68,846 & 78,129 \\
TPS & 77,187 & 59,231 & 68,209 \\
Rataan Marginal & 82,165 & 64,038 & \\
\hline
\end{tabular}

Berdasarkan data rataan marginal dapat disimpulkan bahwa model pembelajaran portofolio lebih baik daripada model kooperatif think pair and share (TPS). Berikut adalah rangkuman uji lanjut pasca anava dengan menggunakan uji Scheffe komparasi antar baris dan komparasi antar kolom.

\begin{tabular}{|c|c|c|c|c|}
\hline$H_{0}$ & $F_{\text {obs }}$ & $F_{b, p: a t z}$ & $\mathrm{P}$ & Kesimpulan \\
\hline $\begin{array}{l}\mu_{2}=\mu_{2} \\
\mu_{2}=\mu_{2}\end{array}$ & $\begin{array}{c}33,528 \\
111,575\end{array}$ & $\begin{array}{l}4,032 \\
4,032\end{array}$ & $\begin{array}{l}<0,05 \\
<0,05\end{array}$ & $\begin{array}{l}\mathrm{H}_{02 z} \text { ditolak } \\
\mathrm{H}_{022} \text { ditolak }\end{array}$ \\
\hline
\end{tabular}

Hal ini dapat dilihat pada gambar profil efek model pembelajaran sebagai berikut:

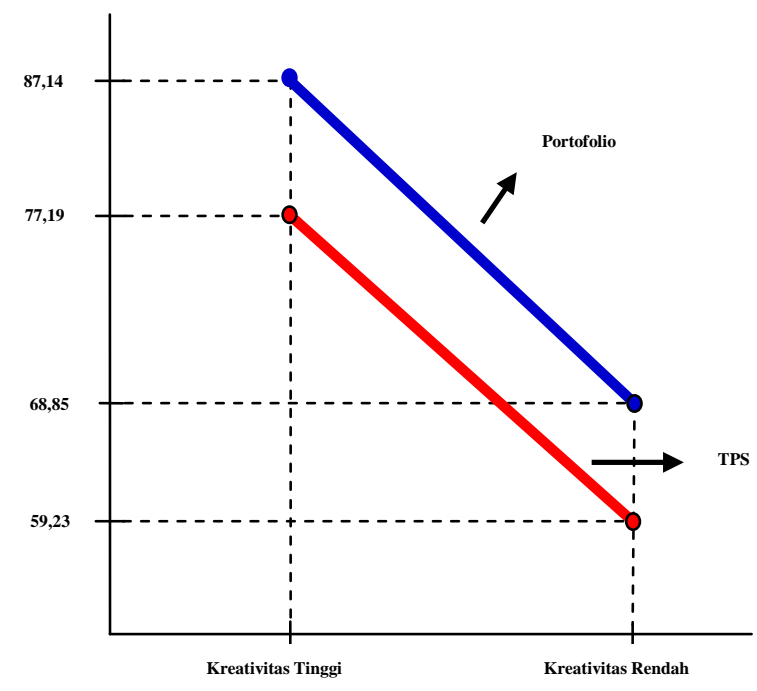




\section{Simpulan}

Berdasarkan pada pembahasan analisis variansi diperoleh kesimpulan sebagai berikut:

1. Ada perbedaan pengaruh antara model pembelajaran portofolio maupun model kooperatif think pair and share (TPS) dalam meningkatkan prestasi belajar siswa kelas VII SMP Negeri 2 Kebonsari materi pokok garis dan sudut tahun ajaran 2011/2012.

2. Ada perbedaan pengaruh antara kreativitas tinggi dan kreativitas rendah terhadap prestasi belajar siswa kelas VII SMP Negeri 2 Kebonsari materi pokok garis dan sudut tahun ajaran 2011/2012.

3. Tidak terdapat interaksi antara model pembelajaran portofolio dan model kooperatif think pair and share (TPS) dengan kreativitas tinggi maupun rendah terhadap prestasi belajar siswa kelas VII SMP Negeri 2 Kebonsari materi pokok garis dan sudut tahun ajaran 2011/2012.

\section{SARAN}

a. Siswa hendaknya lebih aktif dan menciptakan suasana yang kondusif saat proses belajar mengajar berlangsung.

b. Dalam pembelajaran portofolio, sebaiknya siswa lebih giat dan rajin dalam mencari sumber-sumber yang relevan sehingga tugas-tugas yang diberikan kepada siswa dapat diselesaikan secara maksimal.

c. Dalam model pembelajaran TPS, siswa diharapkan lebih aktif dalam diskusi .

\section{DAFTAR PUSTAKA}

Alim Sumarno. 2011. Teknik Assesment Penilaian Portofolio, (http://elearning.unesa.ac.id/myblog/alim -sumarmo/teknik-asesmen-penilaianportofolio, Diunduh 9 Februari 2012).

Aunurrahman. 2009. Belajar dan Pembelajaran. Bandung: Alfabeta.

Budiyono. 2004. Statistika untuk Penelitian. Surakarta: Sebelas Maret University Press.

Conny R Semiawan. 2010. Kreativitas Keberbakatan. Jakarta: Permata Putri Media.
Dewi Salma Prawiradilaga. 2008. Disain Pembelajaran. Jakarta: Kencana Prenada Media Group.

Herman Hudojo. 2005. Pengembangan Kurikulum dan Pembelajaran Matematika. Malang: Universitas Negeri Malang.

Heruman. 2007. Model Pembelajaran Matematika. Bandung: PT Remaja Rosdakarya.

Husaini Usman dan Purnomo Setiady Akbar. 2006. Pengantar Statistika. Jakarta: PT Bumi Aksara.

Jumidi Dkk. 2011. Profesi Buku Pendamping Materi Pelajaran Matematika untuk SMP. Sragen: Akik Pustaka.

Markaban. 2009. Model Penemuan Terbimbing pada Pembelajaran Matematika SMK, (http://p4tkmatematika.org/2009/05/mod el-penemuan-terbimbing-padapembelajaran-matematika-smk/, Diunduh 14 Februari 2012).

Muhammad Zainal Abidin. 2011. Kelebihan dan Kekurangan Penggunaan Portofolio, (http://www.masbied.com/2011/09/14/ke lebihan-dan-kekurangan-penggunaanportofolio/, Diunduh 14 Februari 2012).

Penemuan Terbimbing, 2011. Metode (http://www.masbied.com/2011/09/07/m etode-penemuan-terbimbing/, Diunduh 9 Februari 2012).

Mulyasa. 2002. Manajemen Berbasis Sekolah. Bandung: PT Remaja Rosdakarya.

Nana Sudjana. 2010. Penilaian Hasil Proses Belajar Mengajar. Bandung: PT Remaja Rosdakarya.

Reni Akbar Hawadi. 2004. Akselerasi. Jakarta: PT Grasindo.

Robert E Salvin. 2009. Psikologi Pendidikan. Jakarta: Permata Puri Media. 
Safari. 2005. Penulisan Butir Soal Berdasarkan Penilaian Berbasis Kompetensi. Jakarta: APSI Pusat.

Slameto. 2010. Belajar dan Faktor-Faktor yang Mempengaruhi. Jakarta: PT Rineka Cipta.

SMP Labschool Kebayoran. 2006. Kreativitas, (http://www.labschoolunj.sch.id/smpjkt/materi download.php? id=7, Diunduh 21 Februari 2012).

Sugiyono. 2008. Metode Penelitian Pendidikan. Bandung: Alfabeta.

2005. Statistika untuk Penelitian.

Bandung: Alfabeta.

2011. Metode Penelitian Kuantitatif Kualitatif dan R\&D. Bandung: Alfabeta.

Suharsimi Arikunto. 2003. Dasar-Dasar Evaluasi Pendidikan. Jakarta: PT Bumi Aksara.

2009. Manajemen

Penelitian. Jakarta: PT Rineka Cipta.

Trianto. 2010. Mendesain Model Pembelajaran Inovatif Progresif. Jakarta: Kencana Prenada Media Group. 